\section{PERAN AGENSI BUDAYA DAN PRAKTIK MULTIKULTURALISME DI PERKAMPUNGAN BUDAYA BETAWI (PBB) SETU BABAKAN}

\section{Oleh}

Ariesta Amanda ${ }^{1}$

\begin{abstract}
Abstrak
Penelitian ini bertujuan untuk mengkritisi praktik rekacipta Perkampungan Budaya Betawi (PBB) Setu Babakan melalui agensi sosial yang terlibat dalam pengembangan Perkampungan Budaya Betawi Setu Babakan. Hasil penelitian menunjukkan bahwa Perkampungan Budaya Betawi merupakan hasil rekacipta politik yang dirancang oleh sekelompok elit Betawi dalam Lembaga Kebudayaan Betawi yang dimunculkan sebagai representasi masyarakat Betawi secara umum. Gagasan tersebut kemudian didukung oleh Pemerintah Daerah (Dinas Periwisata dan Kebudayaan) untuk perlindungan tradisi budaya Betawi. Namun dalam praktiknya terdapat kontradiksi atas kebijakan yang dikeluarkan pemerintah daerah dan aplikasi dalam praktik pengelolaan Perkampungan Budaya Betawi. Perkampungan Budaya Betawi Setu Babakan saat ini lebih difungsikan sebagai wisata budaya yang dikomodifikasikan oleh Pemerintah Daerah dengan dalih penyelamatan aset budaya daripada pemberdayaan eksistensi budaya Betawi bagi etnis Betawi itu sendiri. Peranan agensi sosial menunjukkan bahwa pengaruh elit Betawi berperan sebagai pengawas kebijakan dan pengembangan. Akibatnya, pengembangan Perkampungan Budaya Betawi Setu Babakan bersifat top-down dengan adanya dominasi pemerintah yang sangat tinggi.
\end{abstract}

\footnotetext{
${ }^{1}$ Ariesta Amanda, MA adalah alumni Program Studi S2 Sosiologi, Pascasarjana Fisipol UGM. Artikel ini disarikan dari salah satu pembahasan di dalam tesisnya berjudul "Kajian Kritis Praktik Multikulturalisme di Perkampungan Budaya Betawi Setu Babakan" dan telah berhasil diuji pada tanggal 28 April 2016.
}

Kata Kunci:

Agensi Budaya, Perkampungan Budaya, Praktik Multikulturalisme, Budaya Betawi

\section{Abstract}

This study aims to criticize the establishment of Betawi Cultural Village of Setu Babakan by utilizing social agencies involved in the development of the Cultural Village. The study shows that the Betawi Cultural Village is the result of political engineering designed by the elitist groups of the Betawi Cultural Organization who claim themselves as the representatives of the Betawi people. The idea of establishing the cultural village was supported by the local government (the local representatives of the ministry of tourism and culture) who claimed their authority on behalf of the protection of the cultural tradition of Betawi. In fact, by contrast there was a contradiction found in the policy issued by the local government and the management of the cultural village who practice the application. The Setu Babakan Betawi Cultural Village is currently functioned mainly as a site for cultural tourism and thus commodified by the government by claiming for saving the existence of cultural assets. On the other hand, it does not involve a program designed for preserving the cultural inheritance of the Betawi culture in general by empowering the people. The study also shows the role of social agency of Betawi elites' influence who mainly act as watchdogs rather than active participants of the development policies. In general, the development of Setu Babakan Betawi Cultural Village is a top-down policy marked by the dominant intervention by the local government

\section{Keywords:}

Cultural Agency, Cultural Village, Multicultural Practice, Betawi Culture 


\section{Pengantar}

Perkampungan budaya Betawi saat ini bukan hanya wacana, tetapi sudah teraktualisasi di wilayah Setu Babakan, Srengseng Sawah, Jagakarsa, Jakarta Selatan. Pemerintah dalam hal ini PEMDA diwakili oleh Suku dinas pariwisata mulai menunjukkan keseriusannya, bahwa kebijakan yang mereka turunkan mulai diaplikasikan di lapangan. Pengakuan yang diberikan pemerintah atas hadirnya kembali Betawi ditengah masyarakat Jakarta dan sekitarnya kini muncul dengan wajah perkampungan budaya Betawi. Ada beberapa aspek yang kemudian melatarbelakangi Perkampungan Budaya Betawi Setu Babakan menjadi arena praktik multikultural. Dalam setiap kebijakan yang diturunkan pemerintah tidak lepas dari adanya konteks politik, ekonomi, sosial, budaya dan juga pariwisata, mengingat perkampungan budaya Betawi setu babakan merupakan aset budaya yang cukup potensial bagi pemerintah dan kelangsungan Betawi kedepannya. Berikut beberapa uraian terkait beberapa konteks yang melatarbelakangi terbentuknya Perkampungan Budaya Betawi Penasionalisasian tradisi lokal tampaknya telah berjalan cukup lama dalam sejarah perjalanan umat manusia (Hobsbawm, 1989). Sebagian telah berlangsung sejak 200 tahun yang lalu dan sebagian lainnya baru terlaksana beberapa tahun terakhir. Sebagian dari proses ini direkacipta dengan sadar dan sengaja dalam usaha nasionalisasi tradisi lokal, dan sebagian lagi terjadi tanpa disengaja yang akhirnya menuju pada nasionalisasi tradisi lokal. Proses nasionalisasi tradisi lokal terus berjalan hingga kini dalam kedua bentuknya, yang sengaja dinasionalisasikan, serta yang tidak sengaja telah ternasionalisasikan. Baik disengaja atau tidak, tradisi-tradisi lokal dengan wajah dan fungsi baru itulah yang dikategorikan sebagai rekacipta tradisi, mengenai rekacipta tersebut umumnya membahas tujuan serta faktor-faktor yang melatarbelakangi proses rekacipta ini. Hal tersebut senada disampaikan oleh salah satu informan yang merupakan budayawan Betawi sebagai berikut;

"Pada kenyataannya Betawi yang ada di Setu Babakan memang rekacipta, artinya diproduksi lagi secara kultural untuk menyesuaikan perkembangan jaman. Saat ini sangat susah mempertahankan keaslian, karena yang lampau betul-betul sudah hilang bersamaan dengan generasi yang terus berganti"

(Petikan wawancara dengan Informan YS, 12 November 2015)

Proses rekacipta tradisi Betawi memberi peluang luas untuk membahas sisi otoritas dalam proses rekacipta tradisi.Pertama, rekacipta tradisi Betawi dilakukan oleh orang Betawi dan orang nonBetawi, oleh lembaga Betawi dan lembaga non Betawi, oleh lembaga pemerintah dan oleh lembaga non-pemerintah. Kedua, dalam proses rekacipta ini (yang telah dan sedang terus berlangsung sejak tahun tujuh puluhan) ternyata telah terjadi pergeseran kekuasaan dalam arti waktu dan ruang dalam pengambilan keputusan batasan kebetawian.Terdapat perbedaan pendapat terutama pada aspek pelabelan hasil rekacipta, apakah produk rekacipta tersebut dianggap tradisi Betawi sehingga dapat dikategorikan sebagai Betawi atau sebagai non Betawi. Adanya dua pihak utama dalam proses rekacipta ini: Betawi dan non Betawi, lembaga pemerintah dan lembaga non pemerintah, menyebabkan proses ini amat diwarnai dengan pertentangan-pertentangan, suatu prasyarat untuk mengukur sisi otoritas dalam proses ini. Representasi masingmasing kelompok yang terdapat dalam proses rekacipta yang sekaligus menjadi subyek diskusi ini adalah Dinas Kebudayaan DKI yang merupakan representasi Pemda DKI; Lembaga Kebudayaan Betawi yang merupakan representasi masyarakat Betawi; Orang Betawi yang berkiprah dalam proses rekacipta ini umumnya adalah kelompok elit Betawi melalui organisasiorganisasi Betawi. Dua kelompok dalam proses rekacipta ini, khususnya kelompok pemerintah dan Betawi, merupakan 
kelompok-kelompok yang amat berbeda dalam arti kekuasaan. Pernyataan tersebut juga disampaikan oleh salah satu informan yang merupakan budayawan Betawi,

"Jadi tidak ada istilah bottom-up dalam rekacipta Betawi, semuanya di top-downkan karena Betawi punya elit yang menjadi perantara. LKB menjadi perantara yang cukup baik karena memang yang orangorang LKB punya dedikasi terhadap Betawi, berbeda dengan BAMUS yang memang lahirnya setelah LKB. BAMUS tidak menyentuh hingga tataran budaya karena mereka semua hanya politisi saja, yang urusannya juga hanya untuk politik"

(Petikan wawancara dengan Informan YA, 29 Oktober 2015)

Pengertian elit dan kekuasaan di sini akan difokuskan dalam batasan elit dan kekuasaan yang membagi kelompok elit atas dua bagian, yaitu elit yang memerintah yang terdiri dari individu yang secara langsung maupun tidak langsung memainkan bagian yang berarti dalam pemerintahan; elit yang memerintah yang terdiri dari mereka yang tidak termasuk dalam kelompok pertama. Seperti dikatakan Mosca (1939), dalam semua masyarakat, dari yang belum begitu berkembang hingga masyarakat yang sudah kuat dan berkembang pesat, senantiasa muncul dua kelas: kelas yang memerintah dan kelas yang diperintah. Kelas yang pertama senantiasa lebih sedikit jumlahnya, mempunyai monopoli kekuasaan, dan memperoleh semua keuntungan yang timbul karena itu; kelas yang kedua yang jumlahnya lebih banyak, dipimpin dan diawasi oleh kelas pertama. Kelompok pertama ini dapat memerintah karena kelompok ini memang terorganisasi, terdiri dari individu-individu yang lebih unggul. Anggota-anggota dari kelompok ini memiliki atribut yang mendapat penghargaan dan pengaruh dalam masyarakat tempat mereka berada. Kelompok kedua merupakan kelompok elit dari masyarakat yang lebih luas, yang berperan atas nama kelompok yang lebih luas itu. Dalam masyarakat modern, kelompok pertama tidak begitu saja ditempatkan di atas seluruh masyarakat, tetapi berhubungan erat dengan masyarakat melalui kelompok kedua yang kurang berhubungan dengan pelaksanaan kekuasaan, walaupun mereka ini mempunyai pengaruh sosial yang penting. Yang tersebut terakhir adalah kelompokkelompok fungsional dan pemangku jabatan yang memiliki status tinggi dalam suatu masyarakat.

\section{Metode Penelitian}

Penelitian ini menggunakan metode kualitatif dengan wawancara mendalam (indepth interview). Penentuan metode tersebut didasarkan atas kebutuhan data yang mendalam dengan karakteristik, sejarah, dan perkembangan masyarakat Betawi dari dulu hingga saat ini. Sesuai dengan pengertiannya wawancara mendalam merupakan cara yang ditempuh untuk betul-betul mendapatkan akurasi data sesuai dengan kebutuhan peneliti. Dalam pelaksanaannya wawancara tidak dilakukan hanya sekali, melainkan berulang-ulang dengan intensitas yang ditentukan peneliti. Peneliti melakukan pengamatan sebagai data pendukung wawancara untuk mengukur kesesuaian hasil wawancara dengan kenyataan dilapangan. Itulah sebabnya wawancara dilakukan secara silih berganti dengan terus mengecek hasil wawancara dari informan satu ke informan yang lain. Untuk kepentingan menjaga privasi narasumber, maka peneliti tidak dapat menuliskan identitas narasumber secara terbuka.

Analisis secara kualitatif diharapkan mampu mendeskripsikan segala sesuatu situasi atau area populasi tertentu yang bersifat faktual secara sistematis dan akurat dengan menggambarkan atau mendeskripsikan suatu keadaan objek penelitian. Untuk memperoleh fokus dalam penelitian ini, maka saya menentukkan beberapa informan yang diasumsikan memiliki informasi mengenai sejarah perkembangan masyarakat dan perubahan 
di Perkampungan Budaya Betawi (PBB) Setu Babakan. Kriteria utama yang ditentukan peneliti atas pemilihan informan didasari oleh tujuan untuk memperoleh informasi yang dianggap cukup signifikan khususnya mereka yang memahami arah penentuan kebijakan. Sementara itu, informan lain juga merupakan anggota masyarakat yang berada di dalam agensi yang dilibatkan dalam praktek kebijakan menjadikan Kampung Setu Babakan sebagai 'Kampung Budaya'. Mereka ini merupakan warga Betawi yang memiliki pengetahuan mengenai sejarah pengembangan masyarakat dan budaya Betawi.

Penelitian dilakukan di Perkampungan Budaya Betawi (PBB) Setu Babakan, Kawasan Srengseng Sawah, Jagakarsa, Jakarta Selatan yang mana di daerah tersebut merupakan kawasan yang ditetapkan sebagai kawasan konservasi budaya dan lingkungan dengan wajah Perkampungan Budaya Betawi (PBB) Setu Babakan.

\section{Sejarah Pembentukan Perkampungan Budaya Betawi (PBB) Setu Babakan dan Keterlibatan Agensi Budaya Lokal}

Pemda DKI merupakan kelompok elit yang memiliki kekuasaan formal, dan LKB merupakan kelompok elit Betawi yang berfungsi sebagai representasi Betawi, penghubung antara pemda DKI dan masyarakat Betawi. Awal berdirinya organisasi Betawi pada umumnya diprakarsai orang Betawi Kota, sejumlah kecil orang Betawi Tengah, dan tidak ada satu pun orang Betawi Pinggir yang berpartisipasi. Oleh karena itu, dalam diskusi selanjutnya sebutan Betawi menunjuk pada orang Betawi Kota dan Tengah. Hanya ketika berbicara tentang Betawi Pinggir, maka akan disebut label tambahan pada kata Betawi. Sampai beberapa saat yang lalu, bila berbicara mengenai kelompok elit Betawi, kata ini menunjuk pada Betawi Kota dan Betawi Tengah. Kelompok elit agama lebih menunjuk pada kelompok Betawi Tengah, sedang kelompok elit politik lebih menunjuk pada kelompok Betawi Kota. Walaupun kini mulai terdapat pergeseran dan perubahan, lebih dominannya orang Betawi Kota dalam kelompok elit politik dan dominannya orang Betawi Tengah dalam kelompok elit agama merefleksikan sisa sejarah. Sehingga dalam perjalannannya Betawi cukup banyak didominasi oleh peran LKB dan pemerintah. BAMUS dalam hal ini dijadikan penyangga untuk memberikan kekuatan terhadap Betawi di kancah perpolitikan.

Dalam banyak sisi, rekacipta Betawi membutuhkan banyak kucuran dana. Pembangunan demi pembangunan gencar dilakukan, penyalur dana terbesar berasal dari Pemerintah daerah. Pihak swasta sementara ini terbatas menyalurkan bantuan melalui program CSR mereka. Sejak awal dalam upaya mewujudkan rekacipta Betawi tentu salah satu tantangan pemerintah adalah penyediakan dana yang tidak sedikit karena proses ini benar-benar dimulai dari nol dan membutuhkan waktu yang sangat lama. Dana untuk pembebasan lahan, pembangunan, perawatan merupakan hal yang menjadi fokus utama dalam pengembangan PBB setu babakan ini. Hal tersebut juga disampaikan oleh kepala Unit Pengelola Kawasan,

"Kawasan PBB Setu Babakan merupakan konsen pemerintah terutama dalam hal pendanaan, memang ini semua berasal dari pemerintah yang menginginkan hak milik PBB menjadi milik pemerintah. Ini merupakan salah satu langkah pemerintah untuk mengantisipasi kegagalan pengembangan seperti yang terjadi di condet pada masa itu. Pemerintah menginginkan asset yang ada dimiliki dan diatur oleh pemerintah, untuk itu dibentuk juga UPK sebagai tangan kanan pemerintah dalam hal pengelolaan. Tidak menutup kemungkinan bahwa pada masanya nanti ini akan berubah menjadi BLUD"

(Petikan wawancara dengan Informan SA, 27 Oktober 2015) 
Dinas Pariwisata dan Kebudayaan (Disparbud) DKI menganggarkan dana sebesar Rp 254 miliar untuk menyelesaikan pembangunan Perkampungan Budaya Betawi (PBB) Setu Babakan, Jagakarsa, Jaksel. Kepala Disparbud DKI mengatakan, total alokasi anggaran untuk pembangunan PBB Setu Babakan sebesar Rp 291 miliar. Hingga tahun ini, anggaran yang baru terpakai hanya sekitar Rp 37 miliar saja, di antara anggaran tersebut Rp 24 miliar dianggarkan tahun ini. Sisanya direncanakan akan dianggarkan secara bertahap selama lima tahun kepemimpinan Gubernur DKI Jakarta Joko Widodo. Namun karena Gubernur menginginkan pembangunan Setu Babakan dapat dirampungkan dalam kurun waktu dua tahun, maka anggaran pembangunan akan dibagi menjadi dua tahap. Kepemimpinan Ahok saat ini berfokus pada pembebasan lahan untuk percepatan pembangunan zona B dan C.

Di sisi lain, di Jakarta berkembang sektor bisnis informal yang mampu bertahan di tengah badai krisis. Pengalaman krisis pada saat ini menunjukkan bahwa mereka yang bergerak di sektor informal mampu tetap eksis. Sektor informal yang ada disekitar babakan cukup untuk membuat masyarakatnya berada dalam taraf hidup yang baik. Dampak positif yang dirasakan masyarakat sekitar dar pembangunan perkampungan budaya Betawi adalah banyak kunjungan yang menjadi peluang bisnis untuk mengembangkan kuliner khas Betawi. Penggunaan lahan pedagang yang digunakan untuk menjajakan produknya ditempatkan pada sekeliling bantaran setu.

Tercatat ada 224 PKL yang saat ini ada disekitar setu babakan (pendataan PKL Setu Babakan tahun 2015) dengan catatan jumlah tersebut tidak semua pedagang menjual kuliner khas Betawi. Produk yang djual beragam mulai dari soto Betawi, ketoprak, es selendang mayang, toge goreng, kerak telor, kue rangi, bir pletok hingga jajanan pada umumnya seperti bakso, mie ayam, popmi, segala minuman (jus, pop ice). Berikut macam kuliner yang saat ini tersedia di kawasan PBB Setu Babakan.

\begin{tabular}{|cc|}
\hline Kuliner Betawi & Jumlah Pedagang \\
\hline Kerak telor & 24 \\
Ketoprak & 16 \\
Toge goring & 6 \\
Dodol & 21 \\
Makan ringan (akar kelapa, & 16 \\
kembang goyang & 18 \\
\hline Soto Betawi & 10 \\
Gado-gado & 8 \\
\hline Karedok & 4 \\
\hline Pecak ikan mas & 4 \\
\hline Sayur asem & 26 \\
\hline Es selendang mayang & 7 \\
\hline Kue rangi & 5 \\
\hline Lontong sayur & 8 \\
\hline Asinan Betawi & 13 \\
Tape uli & 15 \\
\hline Bir pletok & \\
\hline
\end{tabular}

Tabel 1. Daftar PKL Kuliner Khas Betawi (Sumber : Data primer diolah Peneliti)

Penataan PKL ini masih menjadi pekerjaan rumah pihak pengelola untuk diselesaikan, karena belum ada regulasi yang mengatur keberadaan PKL dibantaran setu. Pengelola sangat mendukung adanya para PKL, artinya ada kesadaran mengenai pengaruh keberadaan mereka di kawasan PBB setu babakan. Hanya saja keberadaan mereka ini sifatnya illegal karena dari pihak Dinas PU yang membatasi penggunaannya dalam suatu regulasi yang menyatakan bahwa disekitar bantaran setu dilarang didirikan bangunan-bangunan walaupun berupa warung-warung tenda sekalipun yang sifatnya temporer. Hanya bangunanbangunan tertentu saja seperti pos jaga, dermaga dan pos kesehatan yang diperbolehkan berdiri secara permanen. Pembatasan ini untuk menghindari adanya dampak negatif seperti tercemarnya lingkungan dan kualitas air di Setu Babakan.

Kondisi yang demikian jelas meresahkan pedagang kaki lima, kesan yang muncul para pedagang adalah tidak ada dukungan dari pihak pengelola. Untuk itu, pengelola terus menerus mencari solusi atas permasalahan yang ada, kemudian muncul 
ide untuk relokasi pedagang dan kemudian dilokalisasi dilahan tertentu yang representatif untuk para pedagang dan pembeli. Zona B dirancang untuk lokalisasi pedagang yang ada dibantaran setu tetapi hingga kini masih dalam tahap pembangunan. Hal tersebut disampaikan oleh salah seorang mantan ketua forum Jibang:

"Saat ini pembangunan masih terus berlangsung, diantaranya pembangunan zona $B$ yang nantinya akan dikhususkan untuk para pedagang. Nantinya akan berkonsep seperti foodcourt atau pusat jajanan Betawi yang kemudian semua makanan bisa didapatkan di zona B itu."

(Petikan wawancara dengan Informan I, 23 Oktober 2015)

Mata pencaharian warga Betawi sebagian besar bergerak dalam sektor informal yang menjadi tumpuan kemandirian ekonomi mereka. Maka pembangunan yang dilakukan janganlah selalu memimpikan kemakmuran dalam semua sisi dan hasrat mencari surplus ekonomi semata. Tetapi pembangunan perlu memperhatikan surplus sosial, seperti, pengalaman belajar bertoleransi dan percaya akan kemampuan sendiri. Sebagai kota Jakarta harus melayani warganya sebagai makhluk budaya, memberikan ruang kontemplatif untuk mempelajari perbedaan budaya dan sejarah. Sehingga tercipta kota yang memihak warganya, dengan berbagai fasilitas publik yang murah seperti transportasi, perpustakaan, museum, berbagai festival rakyat, tanpa meminggirkan salah satu warganya.

\section{Konteks Budaya Betawi}

Budaya Betawi sedikit banyak terwarnai oleh para pendatang yang menetap di Batavia. Salah satu budaya yang mempengaruhi budaya Betawi berasal dari budaya jawa dengan berbagai jenis kesenian wayang. Budaya luar selain jawa juga memiliki peran dalam warna kebudayaan Betawi, seperti budaya bali, bugis, cina, arab dan eropa. Bentuk pengaruh yang dipertahankan hingga saat ini adalah dalam bentuk kesenian topeng, lenong, tanjidor, gambang kromong, dan lain sebagainya (Dinas Kebudayaan DKI, 1995). Sikap egaliter kaum Betawi menjadikan mereka memiliki kebudayaan meltingpot dengan menggabungkan mereka kebudayaan dengan para pendatang. Terjadinya pencampuradukan kebudayaan pada kaum Betawi tentunya tidak secara mentah diterima seutuhnya, namun setengah-setengah dari masing-masing budaya. Akulturasi budaya orang Betawi sangat sering terjadi pada masa kolonial hingga nama Batavia menjadi Jakarta (Saidi, 2001).

Pengadopsian yang setengah-setengah dan tidak memiliki suatu tanda tertentu seperti kerajaan, pada akhirnya orang Betawi menjadikan Islam sebagai dasar kebudayaan Mereka. Melihat segala kebudayaan menggunakan sudut pandang islam, apabila tidak sesuai dengan khasanah islam, maka orang Betawi akan meninggalkannya (Shahab, 2002). Orang Betawi tidak menggunakan stratifikasi sosial dalam kesehariannya. Derajat manusia dianggap terhormat satu sama lainnya, seperti halnya dalam islam. Terdapat dua kedudukan yang disegani oleh orang Betawi yaitu mereka para ulama dan mahir bela diri. Model kepemimpinan dengan orang yang memahami agama dan menjadi juara dalam bela diri merupakan hal yang terus dijaga oleh masyarakat Betawi. Prinsip moral dan etika orang Betawi dalam keseharian sangat erat kaitanya dengan doktrin agama. Hal serupa disampaikan oleh salah satu informan, yaitu;

"Tradisi Betawi sangat kental dengan keislaman. Jaman dulu kalau sekolah ya pasti di sekolah agama atau di pesantren. Kegiatan orang Betawi dulu Cuma ngaji, sholat jamaah di masjid."

(Petikan wawancara dengan Informan RR, 6 November 2015) 
Kreativitas warga, kemampuan mengembangkan budaya dan tradisi, penjagaan terhadap budaya tidak boleh diabaikan. Prinsip egalitarian orang Betawi merupakan modal sosial. Pada bulan Desember 196 Jurnal Masyarakat \& Budaya, Volume 15 No. 1 Tahun, Pemerintah Provinsi DKI Jakarta mengadakan kongres sebagai ajang dan upaya melestarikan kebudayaan Betawi. Kongres tersebut sesuai amanat UU No. 29/2007 tentang Pemprov DKI Jakarta dan SKB Menbudpar dan Mendagri No. 40 dan No. 42 tahun 2008 tentang pedoman Pelestarian Kebudayaan. Pemerintah Propinsi DKI Jakarta wajib mengembangkan budaya lokal Betawi bersamaan dengan budaya lain yang tumbuh berkembang di ibukota. Ada 11 aspek kebudayaan yang dibahas dalam kongres tersebut antara lain: kesenian, kepurbakalaan, kesejarahan, permuseuman, kebahasaan, kesusastraan, tradisi, kehidupan religi, kepustakaan, kenaskahan, dan perfilman.

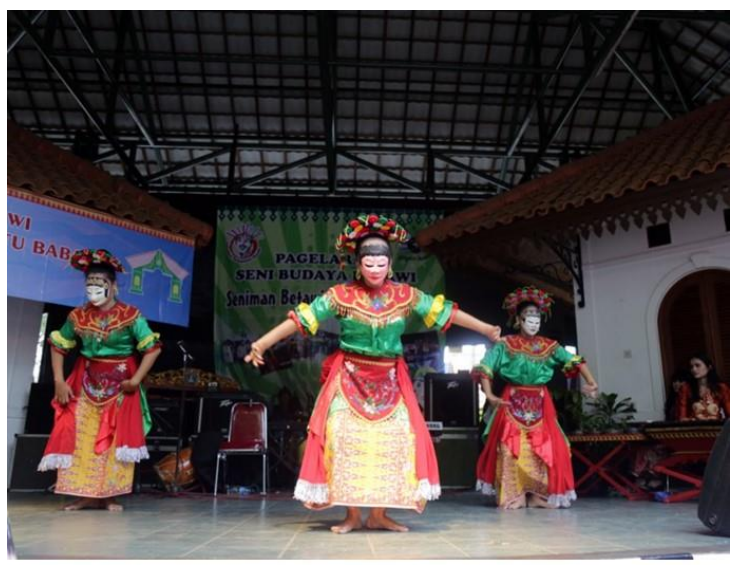

Gambar.1. Tari Topeng Blantek Betawi (Sumber: Dokumentasi Peneliti/Ariesta.A)

\section{Agensi Budaya dan Praktik Multikulturalisme di Perkampungan Budaya Betawi (PBB) Setu Babakan}

Multikulturalisme sebagai ideologi perlu artikulasinya dalam bentuk praktik. Kajian ini menempatkan Perkampungan Budaya Betawi (PBB) Setu Babakan Setu Babakan sebagai praktik artikulasi multikulturalisme yang dibangun oleh pemerintah kota
Jakarta. Dalam perspektif Pierre Bourdieu Perkampungan Budaya Betawi (PBB) Setu Babakan setu babakan dapat dilihat sebagai sebuah arena praktik bagi sejumlah agensi yang terlibat di dalamnya.

Deskripsi mengenai proses rekacipta tradisi Betawi akan terfokus pada peran dari Suku Dinas Kebudayaan DKI dan Lembaga Kebudayan Betawi (LKB) dalam usaha melakukan generalisasi untuk mencapai pengertian siapakah sebenarnya pemegang kekuasaan dalam proses rekacipta tradisi budaya Betawi. Hal itu sekaligus menjawab mengapa kekuasaan berada di tangan mereka, dan apa saja faktor-faktor kontributor penentu kekuasaan tersebut. Menilik Sejarah berdirinya Perkampungan Budaya Betawi (PBB), Suku Dinas Kebudayaan DKI dan Lembaga Kebudayaan Betawi tidak dapat dipisahkan dari latar belakang proses rekacipta tradisi Betawi. Keduanya menjadi agensi dominan, meskipun realitasnya saat ini terdapat beberapa agensi yang turut berpartisipasi dalam mengkonstruksi prktik multikulturalisme di kawasan Perkampungan Budaya Betawi Setu babakan, diantaranya adalah Pengelola yang terdiri dari UPK dan forum Jibang, komunitas seni, dan masyarakat baik Betawi maupun non Betawi (pengunjung). Hal tersebut senada disampaikan oleh narasumber YS yang menyatakan bahwa,

“ LKB merupakan wujud aksi nyata bagi kelangsungan tradisi Betawi. Para sejarawan, budayawan menyatukan visi dan misi sebagai bentuk dari kepedulian terhadap Betawi.Rekacipta tradisi dan perkampungan budaya Betawi menjadi hasil dari segala upaya yang kita perjuangkan kepada pemerintah".

(Petikan wawancara dengan narasumber YS, 12 November 2015)

Latar Belakang rekacipta tradisi Betawi tidak dapat dipisahkan dari peran Gubernur DKI Jakarta periode 1966-1977, Ali Sadikin. Dari sini jelas bahwa proses rekacipta tradisi Betawi diawali oleh kelompok elit pemerintah. Ali Sadikin yang dalam awal pemerintahannya ditantang oleh kas DKI 
yang amat minim (Abayasekere, 1989), serta wajah Jakarta yang kumuh, dilengkapi dengan minat dan kepeduliannya yang besar terhadap seni dan sejarah telah membawa Gubenur Jakarta ini pada program-program pengembangan Jakarta dan Betawi (Shahab, 1994). Usaha ini menuntut penambahan satu devisi dalam struktur pemerintahan DKI yang tugasnya khusus menangani masalah kebudayaan, sehingga dibentuklah satu divisi baru yang dinamakan Dinas Kebudayaan DKI pada tahun 1968 (Shahab, 1994). Ternyata usaha untuk mengangkat keBetawian ke permukaan dalam rangka mewarnai Jakarta dengan tradisi lokal tidaklah semudah yang diperkirakan. Bukan saja miskinnya pengetahuan serta perhatian yang pernah diberikan kepada kelompok ini, melainkan juga banyak ketidakjelasan, variasi serta pertentangan-pertentangan yang terdapat di dalamnya.

Pertentangan-pertentangan ini berupa perbedaan pengertian serta penafsiran Kebetawian antara kelompok-kelompok Betawi, serta antara orang Betawi dan pengamat Betawi. Untuk mengatasi usaha ini Pemda DKI menyelenggarakan 'PraLokakarya Kebudayaan Betawi' pada tahun 1975 (Widjaja 1976). Salah satu hasilnya adalah pembentukan Lembaga Kebudayaan Betawi dengan SK Pemda DKI pada tahun 1976 yang bertugas menangani segala aktivitas kebetawian sebagai kepanjangan tangan dari Dinas Kebudayaan DKI yang terakhir bertugas menangani seluruh masalah kebudayaan yang ada di Jakarta. Chris Wilkes (Harker, 2009) menjelaskan kelas-kelas merupakan kumpulan agen yang menduduki posisi-posisi serupa yang ditempatkan dalam kondisi serupa dan ditundukkan pada pengkondisian serupa, memiliki segala kemungkinan untuk memiliki disposisi dan kepentingan serupa, dan karenanya memiliki segala kemungkinan untuk mereproduksi praktik dan mengadopsi sikap mental serupa.

Habitus dilihat sebagai produk pengkondisian sosial yang dapat ditransformasikan. Identitas sosial biasanya merujuk pada proses interaksi dan identifikasi. Proses ini menjadi dasar identifikasi diri warga Betawi, bagaimana PBB setu babakan di kondisikan secara sosial budaya sebagai representasi dari masyarakat Betawi yang ada di Jakarta. Sebagai mana dikatakan Bourdieu, Habitus adalah sistem diposisi yang bertahan lama dan bisa dipindahkan (transposable), struktur yang di strukturkan diasumsikan berfungsi sebagai penstruktur strukturstruktur, yaitu sebagai prinsip-prinsip yang melahirkan dan mengorganisasikan praktik-praktik dan representasirepresentasi yang bisa diadaptasikan secara objektif kepada hasil-hasilnya tanpa mengandaikan suatu upaya dasar mencapai tujuan-tujuan tertentu atau penguasaan cepat atas cara dan operasi yang diperlakukan untuk mencapainya. Habitus digambarkan sebagai logika permainan (feel for the game) yang mendorong agen bertindak dan beraksi dalam situasi spesifik dengan suatu cara yang tidak selalu bisa dikalkulasikan sebelumnya dan bukan sekedar kepatuhan sadar pada aturanaturan.

Habitus (Jenkins, 2010:120) merupakan sumber dari praksis objektif kehidupan sosial. Menurut pierre Bourdieu, pertama habitus hanya beroperasi dalam kaitannya dengan suatu arena sosial. Kedua, habitus dapat ditransformasikan oleh situasi yang berubah dan aspirasi atau harapan akan berubah bersamanya. Ketiga, habitus dapat dikontrol sebagai hasil dari kesadaran dan sosioanalisis. Disposisi direpresentasikan oleh habitus bersifat : pertama, bertahan lama dalam rentang waktu tertentu dari kehidupan seorang agen. Kedua, bisa di alih pindahkan dalam bentuk praktik di berbagai arena aktivitas yang beragam. Ketiga, struktur yang distrukturkan dengan mengikutsertakan kondisi sosial objektif dalam pembentukannya. Keempat, strukturstruktur yang menstrukturkan dimana praktik yang dilakukan sesuai dengan situasi khusus dan tertentu (Bourdieu, 2010). Hal itu terlihat pada penetapan Perkampungan budaya Betawi dimana pada awalnya ada di Condet kemudian saat ini berada di Setu Babakan, penempatan keduanya tentu karena terdapat kekhasan 
tersendiri yang dimiliki kedua wilayah tersebut yaini memiliki jiwa kebetawian yang kuat di lihat dari everyday life masyarakat setempat yang masih melibatkan unsur tradisi betawi di setiap elemen sosial masyarakatnya.

Habitus di perkampungan budaya Betawi terbentuk karena ada struktur-struktur masyarakat yang menstrukturkan praktik kebetawian. Hal tersebut pada awalnya terjadi secara alamiah, namun untuk menjaganya tetap terjaga maka beberapa agensi seperti Forum Jibang dan sanggar Setu Babakan yang secara terus-menerus melakukan pengkondisian terhadap kualitas aktivitas kebetawian dalam keseharian masyarakat sekitar setu babakan. Pengkondisian tersebut tentu memiliki tujuan atas kepentingan para agensi dengan modal yang mereka miliki agar sejalan dengan tujuan keduanya. Pengkondisian tersebut berwujud aktivitas kebetawian yang rutin dilakukan, seperti latihan seni Betawi setiap rabu malam dan minggu pagi, dan pertunjukan seni itu sendiri setiap hari minggunya. Selain itu kegiatan hari-hari lain juga sangat padat disusun oleh Forum Jibang, seperti kunjungan sekolah, instansi, maupun swasta yang biasanya bergerak dibidang kuliner perhotelan. Semuanya yang datang akan disuguhi berbagai macam atraksi budaya sesuai kebutuhan, mulai dari tari, musik, hingga demo masak Betawi. Sehingga habitus yang diciptakan saat ini lebih mengarah kepada wisata budaya, masyarakat setempat pun pada akhirnya terkonstruksi untuk terlibat dengan menjadi pedagang kuliner maupun souvenir khas Betawi.

Arena sosial dengan nafas kultural tersebut menjadi suatu sistem posisi sosial yang terstruktur (dikuasai oleh individu mauapun institusi) yang mendefinisikan situasi untuk mereka anut. Ini merupakan suatu sistem kekuatan yang ada diantara posisi tersebut; suatu arena yang distrukturkan secara internal dalam konteks relasi kekuasaan. Posisinya ada dalam relasinya dengan dominasi dan subordinasi satu sama lain karena akses yang dapat mereka raih atas modal yang dipertaruhkan di arena tersebut. Eksistensi suatu arena menjelaskann dalam keberfungsiannya dan menciptakan suatu kepercayaan pada sisi partisipan dalam legitimasi dan nilai modal yang dipertaruhkan. Kepentingan yang sah dalam arena ini diproduksi oleh proses historis yang sama memperoduksi arena itu sendiri (Jenkins, 2013).

\section{Multikulturalisme dan relasi kuasa agensi budaya}

Multikulturalisme menjanjikan kesetaraan namun tidak menjamin adanya redistribusi kekuasaan atau sumber daya. Multikulturalisme (Hoon, 2012) menjelaskan perbedaan-perbedaan antara satu budaya dan budaya lainnya, tetapi mengabaikan keragaman di dalam budaya yang sama. Betawi sebagai salah satu etnis yang ada di indonesia tentu telah diakui keberadaanya. Hal itu terwujud dengan perkampungan budaya Betawi yang telah diperjuangkan para elit Betawi sejak tahun 70-an. Berbagai kekuatan hukum bergulir untuk menguatkan setiap kebijakankebijakan yang ditetapkan pemerintah dalam upaya pengembangan budaya Betawi. Meskipun dalam perjalanannya banyak tantangan yang harus dihadapi. Kebijakan yang dikeluarkan pemerintah tidak selalu berjalan dengan semestinya. Perkembangan yang lambat cukup mewarnai proses pengembangan budaya Betawi dinilai sebagian masyarakat sebagai kebijakan setengah hati, pemerintah tidak secara serius dalam memberi ruang Betawi untuk dapat berkembang. Hal tersebut senada disampaikan dalam wawancara peneliti dengan salah satu narasumber yang merupakan ketua Masyarakat Peduli PBB Setu Babakan.

"Kebijakan yang dibuat pemerintah hanya dibibir saja, kebijakannya masih setengahsetengah, karena aplikasinya di lapangan ya akhirnya seperti sekarang itu, lebih banyak yang tidak sesuai dengan master plan.Wujudnya saja megah secara fisik tapi "isinya" masih kosong. Jangan sampai PBB 
Setu Babakan hanya menjadi komoditas pemerintah saja."

(Petikan wawancara dengan Informan LS, 4 November 2015)

Kegagalan Condet tentu saja menjadi bukti nyata kelalaian pemerintah atas kebijakan yang dibuatnya sendiri. Perjuangan setelah condet kemudian dialihkan ke setu babakan juga membutuhkan waktu yang tidak sebentar. Para elit Betawi membutuhkan sekitar 30-an tahun untuk betul-betul mewujudkan aspirasinya. Dalam hal ini peran elit Betawi sebagai agen sekaligus wujud representasi masyarakat Betawi secara umum jelas melakukan negosiasi sebagai proses interaksinya dengan pemerintah.Adapun ranah (field) lebih dipandang Bourdieu (Ritzer, 2010) secara relasional daripada secara struktural. Ranah adalah jaringan relasi antarposisi objektif di dalamnya (Ritzer, 2010). Keberadaan relasirelasi ini terpisah dari kesadaran dan kehendak individu. Ranah menurut Bourdieu merupakan:

(1) arena kekuatan sebagai upaya perjuangan untuk memperebutkan sumber daya atau modal dan juga untuk memperoleh akses tertentu yang dekat dengan hirarki kekuasaan;

(2) hubungan yang terstruktur dan tanpa di sadari mengatur posisi-posisi individu dan kelompok dalam tatanan masyarakat yang terbentuk secara spontan. Ranah kepentingan budaya merupakan ruang interaksi terbatas dimana para elit Betawi melakukan praktik.

(3) Posisi berbagai elit Betawi, pemerintah dan juga masyarakat baik secara individu maupun kolektif dalam ranah terkait dengan jumlah modal yang dimiliki, terutama modal ekonomi dan budaya.

Terdapat empat kategori, yaitu : modal ekonomi, modal sosial (berbagai jenis relasi bernilai dengan pihak lain yang bermakna), modal kultural (pengetahuan sah satu sama lain), dan modal simbolis berupa prestise dan gengsi sosial (Jenkins, 2013).
Agensi dominan seperti Unit Pengelola Kawasan (UPK) saat ini sedang didorong oleh pemerintah daerah untuk melakukan percepatan pembangunan Zona $\mathrm{B}$ dan $\mathrm{C}$ demi pencapaian master plan pada tahun 2020. Unit Pengelola Kawasan (UPK) menjadi tangan kanan pemerintah untuk pelaksanaan teknis di lapangan, agensi yang lain yang terdominasi hanya mampu melakukan pengawasan tanpa kekuatan yang berarti. Artinya saat ini proyek pembangunan sudah diambil alih oleh UPK secara keseluruhan, mulai dari pengelolaan keuangan, koordinasi dengan pemerintah daerah hingga pembebasan sebagian tanah yang masih menjadi milik masyarakat setempat. Arena kultural yang seharusnya mencerminkan multikulturalisme justru menjadi proyek bagi agensi dominan. Master plan yang ditetapkan 5 tahun silam mulai memunculkan berbagai "dugaan" yang meresahkan warga Betawi disekitar Setu Babakan khususnya. Tradisi budaya yang penuh dengan nilai-nilai multikultural saat ini direkacipta menjadi produk yang diperkirakan mampu mendatangkan keuntungan.

\section{Praktik agen dalam Arena Produksi terbatas}

Bourdieu (2010) menjelaskan bahwa disetiap arena, kepentingan tertentu dipertaruhkan bahkan jika kepentingankepentingan tersebut diingkari pelakunya atau pasti ada investasi tertentu meski tidak pernah diakui sebagai sebuah investasi. Dalam praktik multikultural yang terjadi pada masyarakat Perkampungan Budaya tergolong pada arena produksi terbatas. Arena ini dikuasai oleh para produsen (agen dominan) untuk memperoleh laba ekonomi yang biasanya disangkal dan hierarki otoritas didasarkan pada beraneka bentuk laba simbolis. Realitas sosial yang terjadi di Perkampungan Budaya Betawi merupakan kekuatan simbolis yang dipertahankan pihak Forum Jibang mencakup artefakartefak Betawi yang masih dapat dijaga 
hingg saat ini menjadi museum sejarah yang terletak di Zona A.

Berdasarkan hasil wawancara dengan pengelola, didapatkan bahwa saat ini pengelolaan PBB Setu Babakan terkonsentrasi pada UPK, Unit pengelola dari pihak pemerintah terbentuk karena aset di PBB setu babakan tidak semua milik masyarkat, namun ada juga asset pemerintah sehingga harus dikelola oleh pemerintah. Unit pengelola yang beranggotakan pegawai negeri sipil ini akan bersinergi dan berjalan beriringan dengan forum Jibang. Untuk urusan yang berhubungan dengan pemerintahan menyangkut dana dan anggaran akan ditangani oleh unit pengelola kawasan sedangkan untuk pengembangan yang sifatnya kebudayaan akan diurus oleh Forum kajian dan pengembangan perkampungan budaya Betawi yang terdiri dari tokoh masyarakat Betawi. Pernyataan tersebut disampaikan oleh perwakilan UPK, S.A, yang menyatakan bahwa;

\section{"Saat ini UPK dan Forum Jibang sedang berusaha memaksimalkan pelayanan masyarakat. Karena ini termasuk pada masa transisi dimana banyak urusan yang sekiranya masih diurus oleh kami secara bersama-sama.Hingga saat ini semuanya masih berjalan sesuai dengan masterplan, artinya kehadiran UPK akan mempermudah dalam melakukan percepatan pembangunan PBB Setu Babakan."}

(Petikan wawancara dengan Informan SA, 27 Oktober 2015).

Dana untuk pembangunan PBB diperoleh dari pemerintah provinsi DKI Jakarta. Bantuan tersebut berbentuk fresh money (uang) yang dimanfaatkan untuk pembangunan. Dinas pariwisata da kebudayaan juga bersinergi dengan dinas dan instansi lain di lingkup DKI Jakarta yang juga turut berperan serta dalam pembangunan kawasan perkampungan budaya Betawi, antara lain Dinas Pekerjaan Umum, Dinas Kehutanan serta Dinas kebersihan dan Pertamanan.
Ruang interaksi terbatas atau arena didefinisikan Bourdieu (2010:xvii) sebagai ruang yang terstruktur dengan kaidahkaidah keberfungsiannya sendiri, dengan relasi-relasi kekuasaanya sendiri yang terlepas dari kaidah politik dan ekonomi kecuali dalam kasus arena ekonomi dan politik itu sendiri. Terdapat dua bentuk modal yang penting dalam arena produksi kultural (Bourdieu, 2010) yaitu yang pertama, modal simbolis yang mengacu kepada derajat akumulasi prestise, kehormatan dan dibangun diatas dialektika pengetahuan dan pengenalan. Kedua, modal kultural dalam bentuk pengetahuan kultural, kompetisi dan disposisi tertentu. Arena dalam pengembangan PBB setu babakan terstruktur dalam ruang yang berbeda, saat ini jelas arena produksi kultural menjadi tanggungjawab Forum Jibang sebagai mitra dari UPK. Tetapi untuk arena politik dan ekonomi menjadi ranah UPK.

Arena dilihat dalam ruang yang tersedia baik perkembangan historis ruang maupun para produsen berdasarkan strategi, habitus dan kelas serta posisi objektif mereka. Termasuk struktur arena yaitu posisi yang ditempati para produsen dan legitimasi sebagai produk kultural. Bagi Bourdieu (2010) ekonomi arena kultural didasarkan pada suatu kepercayaan khusus tentang apa yang membentuk sebuah karya kultural dan nilai estetis atau nilai sosialnya. Arena (Jenkins, 2010) adalah suatu sistem posisi sosial yang terstruktur yang dikuasai oleh individu atau instutusi. Arena didefinisikan suatu perjuangan dimana strategi manusia dikaitkan dengan peneguhan atau peningkatan posisi mereka sehubungan dengan pendefinisian modal para arena.Arena kekuasaan dianggap sebagai arena dominan dalam masyarakat. Arena kekuasaan adalah sumber relasi kekuasaan hierarkis yang menstrukturkan arena lain. Berikut bagan yang menggambarkan relasi kekuasaan dalam pengembangan PBB Setu Babakan. 


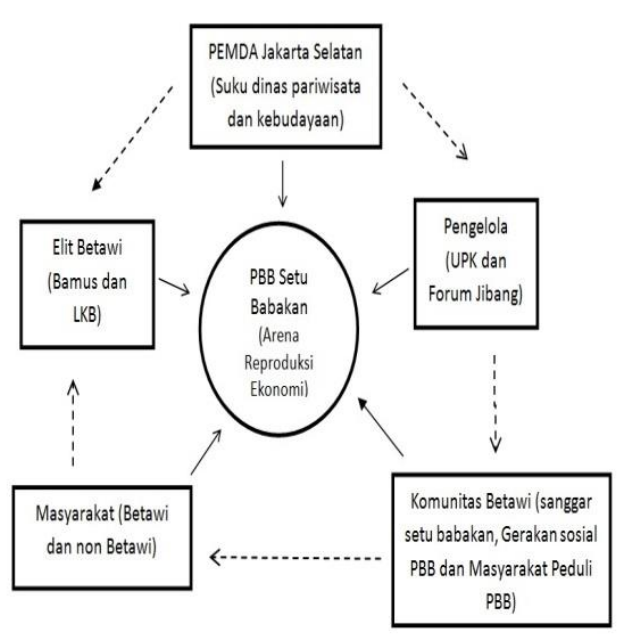

Gambar.2. Bagan Relasi Kekuasaan PBB Setu Babakan (Sumber: Analisis Peneliti)

\section{Perolehan (Keuntungan) dalam praktik pertukaran antar agen}

Hubungan relasional yakni struktur objektif dan representasi subjektif, agen dan pelaku, terjalin secara dialektik, saling mempengaruhi, tidak saling menafikan, tapi saling bertaut dalam sebuah social practice (praktik sosial), antara lain;

(1) modal ekonomi yang mencakup alat-alat produksi (mesin, tanah, dan buruh), materi (pendapatan dan benda-benda), dan uang;

(2) modal budaya (keseluruhan kualifikasi intelektual yang bisa diproduksi melalui pendidikan formal maupun warisan keluarga);

(3) modal sosial atau jaringan sosial;

(4) modal simbolik (segala bentuk prestise, status, otoritas dan legitimasi yang terakumulasi sebagai bentuk).

Praktik sosial merupakan integrasi antara habitus dikalikan modal dan ditambahkan ranah. Praktik sosial dapat dirumuskan sebagai beikut: (Habitus x Modal) + Ranah = Praktik. Modal merupakan sebuah konsentrasi kekuatan spesifik yang beroperasi dalam ranah dan setiap ranah menuntut individu untuk memiliki modal khusus agar dapat hidup secara proporsional dan bertahan di dalamnya. Dalam ranah pertarungan sosial akan selalu terjadi. Mereka yang memiliki modal dan habitus yang sama dengan kebanyakan individu akan lebih mampu melakukan tindakan mempertahankan atau mengubah struktur dibandingkan dengan mereka yang tidak memilikimodal. Ranah (field) menurut Bourdieu lebih bersifat relasional daripada struktural. Jadi ranah (field) bukanlah interaksi atau ikatan lingkungan bukan pula intersubyektif antar individu. Penghuni posisi mungkin agen individual atau lembaga, dan penghuni posisi ini dikendalikan oleh struktur lingkungan. Dalam kehidupan sosial terdapat sejumlah lingkungan semi-otonom, misalnya: kesenian, keagamaan, ekonomi dan semuanya dengan logika khusus sendirisendiri membangkitkan keyakinan di kalangan agensi mengenai sesuatu yang dipertaruhkan dalam ranah (lingkungan).

Boudieu (dalam Ritzer, 2010) menyatakan bahwa ada tiga langkah proses untuk menganalisis ranah, yaitu:

(1) menggambarkan keutamaan ranah (lingkungan) kekuasaan (politik) untuk menemukan hubungan setiap lingkungan khusus dengan lingkungan politik;

(2) menggambarkan struktur objektif hubungan antar berbagai posisi di dalam ranah tertentu;

(3) menentukan ciri-ciri dan kebiasaan agen yang menempati berbagai tipe posisi di dalam suatu ranah.

Posisi agen ditentukan oleh jumlah dan bobot relatif dari modal yang mereka miliki. Bourdieu membahas empat macam modal yaitu: modal ekonomi, kultural (berbagai pengetahuan yang sah), sosial (hubungan yang bernilai antara individu) dan simbolik dari kehormatan dan prestise seseorang.

Pertukaran modal seperti modal simbolik dilakukan sebagai upaya untuk mendapatkan legitimasi pemilikan berbagai 
tingkat dan konfigurasi ketiga bentuk modal yang lainnya (modal ekonomi, modal sosial dan modal budaya). Dalam praktiknya PBB setu babakan agen saling bertukar modal, hal tersebut terihat pada keseharian aktivitas yang ada di sekitar kawasan setu babakan. Pemerintah dalam hal ini mempunyai modal ekonomi yang cukup untuk bertukar dengan lahan masyarakat yang akan dialihfungsikan sebagai pengembangan PBB Setu Babakan. Modal sosial dan modal budaya juga dipertukarkan masyarakat Betawi dengan para pengunjung, dimana para pengunjung dapat menikmati keseharian masyarakat Betawi yang ada di setu babakan sekaligus memperoleh keuntungan secara ekonomi dengan berjualan makanan maupun minuman khas Betawi. Reproduksi sosial dilakukan agen untuk mendapatkan ketrampilan mengatur simbol sosial. Modal sosial (Field, 2010) adalah jumlah sumber daya, aktual atau maya yang berkumpul pada seorang individu atau kelompok karena memiliki jaringan tahan lama berupa hubungan timbal balik perkenalan dan pengakuan yang sedikit banyak terinstitusionalisasikan.Sedangkan menurut Coleman (Field, 2010) modal sosial adalah seperangkat sumber daya yang melekat pada hubungan keluarga dan dalam organisasi sosial komunitas dan yang berguna bagi perkembangan kognitif atau sosial anak atau orang yang masih muda.

Modal sosial yang dimiliki masyarakat sekitar mendorong kesadaran masyarakat untuk aktif menjadi bagian dari pengembangan perkampungan budaya Betawi, meskipun prosentasenya belum maksimal. Hal tersebut senada di dalam penjelasan Putman yang mendefinisikan modal sosial (Field, 2010) sebagai bagian dari kehidupan sosial seperti jaringan, norma dan kepercayaan yang mendorong partisipan bertindak bersama secara lebih efektif untuk mencapai tujuan-tujuan bersama. Modal budaya mengeksplorasi praktik multikulturalisme. Modal budaya Bourdieu (Damsar, 2009) dibatasi sebagai budaya pengetahuan dan kompetensi yang dibutuhkan untuk membuat pembedaan atau penafsiran nilai.Modal budaya merupakan kepemilikan kompetensi atau pengetahuan kultural yang menuntun selera bernilai budaya dan pola-pola konsumsi tertentu, yang dilembagakan dalam bentuk kualifikasi pendidikan. Pernyataan yang disampaikan oleh informan I terkait kondisi kaderisasi untuk kompetensi dan pengetahuan budaya Betawi, bahwa;

"Salah satu tantangan yang saat ini dinilai kami cukup berat adalah kaderisasi seniman Betawi, karena masih sangat sedikit jiwa muda yang peduli terhadap Betawi. Bahkan SMA maupun SMK yang ada dijakarta semakin sedikit yang bermuatan lokal Betawi. Selain karena kondisinya sudah tergabung antara pendatang dan Betawi, muatan lokal Betawi pun masih belum terkualifikasi secara pendidik."

(Petikan wawancara dengan Informan I, 23 Oktober 2015)

Untuk mengatasi permasalahan diatas dalam kaitannya dengan modal budaya, PBB setu babakan sedang mengkondisikan sekolah khusus kesenian yang saat ini masih dalam proses pembangunan. Sekolah Menengah Kesenian (SMK) ini diperuntukkan bagi siswa yang ingin memperdalam bidang keseniannya, selain itu SMK ini juga dipersiapkan bagi proses kaderisasi seniman Betawi. Karena pada kenyataannya saat ini masih sangat sedikit untuk generasi muda yang mampu memahami Betawi secara mendalam. Diharapkan SMK ini mampu mempersempit kemungkinan punahnya seniman Betawi, harapannya ke depan ini akan terus berkelanjutan dan menarik minat yang lebih banyak lagi. Bourdieu melihat bahwa sistem pendidikan sangat besar perannya dalam mereproduksi dan melestarikan relasi kekuasaan dan hubungan kelas yang ada di masyarakat. 


\section{Kontradiksi dalam Praktik Pengelolaan Perkampungan Budaya Betawi (PBB) Setu Babakan}

Perkampungan Budaya Betawi sebagai representasi kehidupan masyarakat Betawi di Jakarta telah berdiri lebih dari 10 tahun yang lalu. Pada awalnya konservasi perkampungan budaya Betawi semata-mata untuk dua kepentingan, yaitu sejarah dan identitas (Sejarah perkembangan pembangunan kota Jakarta dan pelestarian identitas budaya masyarakat Betawi). Konsep perkampungan pun menjadi pro dan kontra pada awal perencanaan, beberapa budayawan menyatakan bahwa ketakutan mereka terhadap gagalnya condet akan terulang. Pro dan kontra yang terjadi adalah seputar penafsiran akan kampung dan perkampungan yang dipahami berbeda. Jika pola kampung, pastinya tidak perlu terlalu banyak konsep karena ada rekayasa di lingkungan sosial "kampung". Berbeda dengan konsep perkampungan yang kemudian menjadi Perkampungan Budaya Betawi adalah merupakan sebuah perkampungan rekayasa yang nantinya akan difungsikan sebagai kawasan konservasi lingkungan dan juga konservasi budaya Betawi itu sendiri.

Pasalnya jika konsepnya tidak direncanakan secara matang serta arah kelanjutan kedepannya akan seperti apa nantinya dikhawatirkan akan kembali gagal. Konsep perkampungan itu sendiri salah satunya muncul dari ide narasumber YS sekitar tahun 1999. Beberapa kriteria disampaikan YS yaitu;

"Diantaranya menempatkan setu babakan karena merupakan wilayah dengan resapan air dan wadah penampungan air (setu) di Jakarta selatan. Setidaknya dinamakan perkampungan budaya Betawi tujuannya adalah tetap menjaga keaslian dailylife masyarakat setu babakan yang mayoritas betawi dengan beberapa pendukung untuk menarik wisatawan seperti wisata budaya, wisata agro dan wisata kuliner betawi"

(Petikan wawancara dengan Informan YS, 12 November 2015)
Senada dengan konsep perkampungan yang selama ini diwujudkan, warga setempat khususnya warga Betawi mengharapkan bahwa kelestarian kampung setu babakan sebagai kampung Betawi pun tetap terjaga. Berdasarkan Hasil wawancara peneliti dengan salah seorang Ketua RT menyatakan bahwa tidak setuju jika menjadi tempat wisata saja.

"Jujur saya tidak setuju kalau ini jadi tempat wisata, nantinya tidak sesuai dengan judulnya Perkampungan Budaya, dimana masyarakatnya turut menjadi bagian. Nah kalo jadi tempat wisata, masyarakatnya kemana. Tidak lagi melibatkan masyarakat tentunya karena fokusnya sudah pariwisata. Sekarang juga sebenernya Perkampungan budayanya sudah tidak kental seperti jaman dulu, karena yang difokuskan hanya masalah pembangunan fisik saja tetapi masyarakatnya tidak diperhatikan."

(Petikan wawancara dengan informan BR, 7 Oktober 2015)

Pada awal pembangunan rencana dipublikasikan melalui lokakarya yang dilakukan 31 Agustus 1999, menyatakan dengan jelas bahwa hasilnya dimulai dengan pembentukan Tim Asistensi Perkampungan Budaya Betawi, dengan beberapa fokus yakni Perkampungan Budaya Betawi jangan hanya menjadi akuarium budaya, maka yang perlu dipersiapkan adalah penguatan dailylife Betawi, komunitas Betawi, sumber daya manusia, kaderisasi baru kemudian pengembangan fisik dan wisata (Yasmine Z. $S$, 1999). Selain itu penekanan Tim Asistensi Perkampungan Budaya Betawi juga menitikberatkan pada 3 prinsip yaitu tidak ada penggusuran, tidak ada pembebasan dan yang terakhir adalah meminimalkan pembangunan fisik. Konsepnya tidak seperti membuat kampung baru, bangunanbangunan yang ada tetap seperti apa adanya, yang kemudian akan dibangun pemerintah hanya fasilitas-fasilitas termasuk perbaikan akses masuk, gedung kesenian, mushola, kantor pengelola dan lain sebagainya. Setelah masa-masa sulit 
pada awal pembangunan dan pengelolaan terlewati, konservasi lingkungan pun terus berjalan dari mulai penanaman pohon hingga pelepasan bibit ikan di setu dilakukan pemerintah. Tetapi konservasi budaya ini lah yang sepertinya mengalami pergeseran dari tujuan awal untuk kepentingan sejarah dan identitas, kini lebih cenderung kepada pengakumulasian kepentingan wisata. Hal senada ditegaskan oleh narasumber yang lain, yaitu L:

"Anda lihat sendiri saja bagaimana wujudnya sekarang, bagi saya kantor UPK saja sudah terlampau mewah. Juga bangunan-bangunan lain, itu sama sekali tidak mencerninkan masyarakat Betawi yang egaliter."

(Petikan wawancara dengan Informan LS, 4 November 2015)

Konsep perkampungan yang pada awalnya diagung-agungkan pun pada kenyataannya lambat laun diragukan pula keberadaannya. Hal tersebut terlihat pada pola pengembangan yang sejak 5 tahun terakhir direncanakan pemerintah bekerjasama dengan pihak pengelola. Perencanaan besar-besaran dilakukan hingga terbentuk tiga zonasi wilayah yang akan terus dikembangkan hingga 2020 mendatang. Atmosfer perkampungan jelas tersisihkan dengan perencanaan yang serba 'mewah'. Dana yang dikucurkan bahkan mencapai lebih dari 250 miliar. Perkampungan yang polanya alamiah, asri dan tidak direkayasa secara berlebihan sudah dialihkan dengan pola master plan yang tujuannya lagi-lagi untuk wisata. Alih-alih menunjung tinggi tradisi Betawi tetapi yang terlihat hanyalah semacam museum Betawi, karena miniatur rumah Betawi di zona A sudah terbangun yang belum dimaksimalkan fungsinya. Tujuan yang dicapai hanya untuk sejarah saja, menjadi tontonan masyarakat Betawi maupun non Betawi yang ingin melihat Betawi di masa lampau. Berkaitan dengan representasi, YS mengungkapkan dengan tegas bahwa saat ini belum merepresentasikan Betawi;
"Kampung Betawi setu babakan belum mewakili kampung Betawi. Karena ketika datang atmosfer yang terasa masih sama dengan kampung yang lain, memang tidak mudah untuk menampilkan sebuah kampung rekacipta. Belum lagi dampak pariwisata terhadap perkembangan masyarakat lokal."

(Petikan wawancara dengan informan YS, 12 November 2015)

Dalam proses pengembangannya pun terjadi pro kontra antara pedagang yang menempati pinggiran setu dengan pengelola. Wacana relokasi ditentang oleh para pedagang, karena bagi para pedagang penyediaan lahan yang baru belum siap. Berikut pernyataan salah seorang informan, BJ terkait hal tersebut,

"Para pedagang emosi karena tiba-tiba ada segerombolan satpol PP datang untuk merobohkan bangunan $P K L$, alasannya nantinya akan direlokasi ke Zona $B$, tapi masalahnya sampai sekarang zona $B$ belum juga rampung dibangun, bahkan nantinya banyak persyaratan jika ingin berjualan kembali di Zona B."

(Petikan wawancara dengan informan BJ, 6 November 2015)

Keterangan informan tersebut juga menambahkan bahwa pihak pengelola terlalu terburu-buru untuk masalah relokasi, disiapkan dulu tempatnya baru tempat yang lama digusur. Jalan tengah pada saat proses penggusuran pada akhirnya menyeleksi bangunan PKL yang menyalahi aturan, misal menganggu pembuangan air/saluran air maupun bangunan yang ditempatkan tidak pada tempatnya, bangunan-bangunan tersebut yang pada akhirnya digusur dan sisanya masih ada walaupun tidak terlalu banyak. Selain itu proses pembebasan tanah hingga saat ini pun belum rampung dilakukan, kenyataannya terdapat hambatanhambatan yang pada akhirnya mempersulit percepatan pembangunan. Berikut disampaikan narasumber SA dengan penjelasannya terkait hal tersebut diatas, 
"Saat ini yang perlu dilakukan pemerintah untuk mengantisipasi kegagalan adalah dengan melakukan pembebasan tanah warga untuk dapat menjadi milik pemerintah. Agar dalam proses pembangunan tidak terlalu banyak penolakan."

(Petikan wawancara dengan informan SA, 27 Oktober 2015)

\section{Kesimpulan}

Secara keseluruhan melalui kajian agensi dan reproduksi budaya melalui ranah social menurut Pierre Bourdieu, maka dapat disimpulkan bahwa Perkampungan Budaya Betawi (PBB) Setu Babakan menjadi suatu 'arena kultural' yang berada dalam posisi subordinat atau terdominasi dalam arena kekuasaan dimana agensi menjalankan prinsip legitimasinya didasarkan pada kepemilikan modal ekonomi atau politik. Bisnis seni dan pertunjukan menjadi sekedar suatu praktik perdagangan barangbarang yang kurang berharga (priceless) dikarenakan menjadi bagian dari logika ekonomi pra-kapitalis yang dieksploitasi oleh kelas sosial menengah atas tertentu (elit) dalam agensi reproduksi budaya Betawi tersebut. Dalam hal ini, wujud Perkampungan Budaya Betawi yang fungsi utamanya didefinisikan sebagai 'penolakan' habis-habisan terhadap praktik 'yang komersial', pada hakikatnya merupakan penyangkalan kolektif terhadap kepentingan dan keuntungan (profits) komersial yang dapat menghidupi struktur secara bersama-sama.

Bourdieu (2010) mengatakan bahwa di dalam usaha mengejar laba 'ekonomi' yang bersifat tunggal, agensi memperlakukan bisnis barang-barang kultural sama seperti bisnis-bisnis lainnya dan semata-mata menyesuaikan diri dengan permintaan klien (pengunjung) yang cara memandang selera seninya dikonstruksi secara tunggal pula, padahal juga terdapat ruang untuk mengakumulasikan modal simbolis.
Meskipun di sisi lain, modal simbolis ini harus dipahami sebagai modal ekonomi atau politik yang dapat disangkal bahkan disalahkenali (misrecognized) dengan cara melegitimasi adanya suatu 'kredit' (pinjaman) dalam kondisi tertentu dan hanya dapat dilegitimasikan apabila dalam jangka waktu panjang mampu menjamin adanya laba 'ekonomis'.

Singkatnya ketika satu-satunya modal efektif yang bisa digunakan adalah modal 'legitimate' (modal yang dilegitimasikan) yang sebenarnya dengan sengaja dikondisikan untuk secara keliru dikenali (misrecognized) sebagai 'prestise atau otoritas' maka modal ekonomi yang umumnya dibutuhkan oleh kegiatankegiatan kultural tidak bisa selalu mengamankan laba spesifik yang diproduksi arena. Hal ini dikarenakan modal yang dilegitimasikan itu bukan menjadi laba ekonomis yang selalu dapat dikonversi ulang menjadi laba ekonomis, kecuali melalui kinerja modal simbolis.

Dunia usaha yang menyangkal ekonomi yang dijalani oleh para 'bankir kultural' tempat dimana seni dan bisnis bertemu dalam praktik multikultural, telah menempatkan keduanya menjalani peran sebagai kambing hitam sehingga jarang dianggap bisa berhasil bahkan dalam pengertian ekonomis, kecuali praktik itu dibimbing oleh penguasaan atas hukum'hukum keberfungsian' arena dimana barang-barang kultural diproduksi dan diedarkan (Bourdieu, 2010). Fakta yang berlangsung di dalam reproduksi budaya dan agensi kesenian yang meneguhkan penyangkalan ekonomi ternyata bukan secara sederhana merupakan topeng ideologis ataupun upaya menghindari kepentingan ekonomi, melainkan menjelaskan mengapa di satu sisi para produsen baru yang hanya bermodal keyakinan bahkan dapat memapankan diri mereka di dalam pasar mengandalkan modal cultural yang dilegitimasikan melalui nilai-nilai yang dirujuk oleh figur-figur dominan dalam mengakumulasi modal simbolis mereka. Di sisi lain, fakta semacam itu seakan-akan membenarkan 
pengetahuan bahwa hanya mereka yang mampu menyesuaikan diri dengan batasanbatasan ekonomis yang terpateri di dalam 'ekonomi penuh penyangkalan' ini sajalah yang bisa memperoleh laba ekonomis yang maksimal melalui modal simbolis mereka.

Kontradiksi demi kontradiksi yang terjadi dalam pengelolaan Perkampungan Budaya Betawi (PBB) Setu Babakan menjadi cermin bahwa koordinasi antara pihak pemerintah dan juga institusi lain yang terkait dengan pengelolaan Perkampungan Budaya Betawi kurang terjalin dengan baik. Tujuan luhur yang ingin dicapai LKB sebagai representasi budaya Betawi dan masyarakat Betawi pada umumnya, akhirnya hanya "mimpi" belaka ketika berbagai kepentingan yang mengatasnamakan pribadi maupun instansi menjadi penyebab utama Perkampungan Budaya Betawi (PBB) Setu Babakan mengalami alih fungsi. Pentingnya pemahaman kesatuan visi dan misi pembangunan Perkampungan Budaya Betawi menjadi kunci atas keberhasilan seluruh pihak dalam mengkonservasi budaya Betawi di Jakarta.

\section{DAFTAR PUSTAKA}

Barker Chris. (2004). Cultural Studies : teori dan praktek. Yogyakarta : Bentang.

Beky Mardani, dkk. (2014). Setu Babakan Dari Penelitian Ke Penelitian. Jakarta : Suku Dinas Kebudayaan Kota Administrasi Jakarta Selatan.

Bikhu Parekh. (2008). Rethingking multikulturalism : cultural diversity and pilotical theory.Cambridge : Harvard University press.

Bourdieu, Pierre. (2010).Arena Produksi Kultural : Sebuah kajian sosiologi budaya.Bantul : Kreasi Wacana.

Castle, Lance. (2009). Profil Etnik Jakarta. Depok: Masup Jakarta.
Clarke Simon. (2008). Culture and Identity in hand book of cultural analysis. London sage publication.

Damsar. (2009). Sosiologi Ekonomi. Jakarta : kencana

Field, John. (2010). Modal Sosial. Bantul : Kreasi Wacana.

Harker, Richard. Chelen Mahar. Chris Wilkes. 2009. Habitus Modal Ranah Praktik: Pengantar paling Komprehensif kepada pemikiran Pierre Bourdieu. Yogyakarta : Jalasutra.

Husnaini Usman. 1995. Metodologi Penelitian Sosial.Jakarta : Bumi Aksara.

Hobsbawm, E. dan T. Ranger.1987. The Invention of Tradition. Cambrige: Cambrige University Press.

Jenkis, Richard. 2010. Membaca Pikiran Pierre Bourdieu. Bantul : Kreasi Wacana.

Miles dan Huberman. 1992. Analisis Data Kualitatif. Jakarta : Universitas Indonesia Press.

Ramón Máiz and Ferran Requejo. 2005. Democracy, Nationalism and Multiculturalism. London : Frank Cass Publishers.

Saidi,R. 2001. Profil orang betawi : Asal muasal, kebudayaan dan adat istiadatnya. Jakarta : PT. Gunara Kata.

Saidi, Ridwan. 2002. Babad Tanah Betawi. Jakarta: PT Gria Media Prima.

Shahab, Y. Z. 1997. Betawi dalam Perspektif Kontemporet : Perkembangan, Potensi dan Tantangannya. Jakarta : Lembaga Kebudayaan Betawi.

Shahab, Yasmine Z.(2004). Identitas dan Otoritas Rekonstruksi Tradisi Betawi. Depok: Laboratorium Antropologi FISIP-UI.

Sugiyono. (2010). Memahami Penelitian Kualitatif. Bandung : Alfabeta. 
Tariq Madood. (2013). Multiculturalism. Polity Press : Cambridge CB2 1UR, UK.

Will Kymlica. (2002). Kewargaan Multikultural. Jakarta : LP3ES. Hal.38

Yahya AS, dkk. (2014). Sejarah Perkampungan Budaya Betawi Setu Babakan : Demi Anak-Cucu. Jakarta : Suku Dinas Kebudayaan Kota Administrasi Jakarta Selatan.

\section{Jurnal :}

Stephen may. (2003). Critical multiculturalism. Peter Laang : Counterpoints, Vol. 168, Critical Theory and the Human Condition FOUNDERS AND PRAXIS.

Patrick west.(2005). The Poverty of Multiculturalism. Studies: An Irish Quarterly Review, Vol. 94, No. 374 (Summer, 2005), pp. 151-158 : Irish Province of the Society of Jesus.

Alan Singer. (2010). Why Multiculturalism Still Matters. Race, Gender \& Class, Vol. 17, No. 1/2 (2010), pp. 10-22. Jean Ait Belkhir, Race, Gender \& Class Journal.

Shahab, Y. Z. (2002). Lenong.Jurnal betawi Media Komunikasi Sosial Budaya. No.1

Pirous, Iwan Meulia. (2011). Jakarta: Kota Yang Berpihak pada Warga?, makalah pada seminar sehari "Jakarta Kota Multikultural Yang Melayani Warga”. Jakarta, 27 Juli 2011.

Windarsih, Ana. (2013). Jurnal Masyarakat \& Budaya, Volume 15 No.1

\section{Skripsi :}

Muhamad Lutfi Firdaus. 2015. Berpikir kritis pada masyarakat betawi. Skripsi : Fakultas Psikologi, Universitas Gadjah Mada.

Leski Rizkinaswara Yustafa. 2015. Strategi pengembangan Perkampungan budaya
Betawi Setu babakan Sebagai daya Tarik Wisata Budaya Di Provinsi DKI Jakarta. Skripsi : Prodi Pariwisata, Fakultas Ilmu Budaya, Universitas Gadjah Mada.

\section{Peraturan Perundang-undangan :}

Peraturan Daerah Provinsi DKI Jakarta Nomor 3 Tahun 2005 Tentang Penetapan Perkampungan Budaya Betawi di Kelurahan Srengseng Sawah, Kecamatan Jagakarsa, Kotamadya Jakarta Selatan.

Peraturan Daerah Provinsi DKI Jakarta Nomor 1 Tahun 2012 Tentang Rencana Tata Ruang Wilayah 2030, sebagaimana dimaksud dalam Pasal 71 bahwa Kawasan Perkampungan Budaya Betawi di Situ Babakan merupakan Kawasan Warisan Budaya.

Keputusan Gubernur Provinsi DKI Jakarta Nomor 92 Tahun 2000 Tentang Penataan Lingkungan Perkampungan Budaya Betawi di Kelurahan Srengseng Sawah, Kecamatan Jagakarsa Kotamadya Jakarta Selatan.

Peraturan Gubernur Provinsi DKI Jakarta Nomor 129 Tahun 2007 tentang Lembaga Pengelola Perkampungan Budaya Betawi di Kelurahan Srengseng Sawah, Kecamatan Jagakarsa, Kota Administrasi Jakarta Selatan.

Peraturan Gubernur Provinsi DKI Jakarta Nomor 151 Tahun 2007 tentang Pembangunan Perkampungan Budaya Betawi di Kelurahan Srengseng Sawah, Kecamatan Jagakarsa, Kota Administrasi Jakarta Selatan.

Keputusan Gubernur Provinsi DKI Jakarta Nomor 754 Tahun 2008 Tentang Susunan Pengurus Lembaga Pengelola Perkampungan Budaya Betawi.

Keputusan Gubernur Provinsi DKI Jakarta Nomor 1837 Tahun 2010 sebagaimana telah diubah menjadi Keputusan Gubernur Provinsi DKI Jakarta Nomor 1745 Tahun 2011 tentang Penetapan Lokasi untuk Perluasan Pembangunan Perkampungan 
Jurnal Pemikiran Sosiologi Vol. 3 No. 2, Agustus 2016

Budaya Betawi di Situ Babakan Jalan Moch.

Kahfi II, Kelurahan Srengseng Sawah,

Kecamatan Jagakarsa, Kota Administrasi

Jakarta Selatan. 